\title{
Russian Orthodox Parish Family Clubs of Sobriety. Specific of rehabilitation work (1992-2016)
}

\author{
Baburin Alexey ${ }^{1}$, Sobornikova Ekaterina², \\ Borisova Olga ${ }^{3}$, Magay Andrey ${ }^{1}$ \\ ${ }^{1}$ Department of endogenous psychological disorders and affective state research of Mental \\ Health Research Center (MHRC), Interregional social movement for Family Clubs of Sobriety \\ (ISM FCS), Moscow, Russia. ${ }^{2}$ Russian Medical Academy of Postdegree Education, the deputy \\ director on scientific work, Interregional social movement for Family Clubs of Sobriety (ISM \\ FCS), Moscow, Russia, ${ }^{3}$ Department of endogenous psychological disorders and affective state \\ research of Mental Health Research Center (MHRC), Moscow, Russia
}

Copyright (C) 2017 KBCSM, Zagreb

e-mail: alcoholism.kbcsm@gmail.com•www.http//hrcak.srce.hr/acoholism
According to WHO report published in 2014 Russia ranks world №4 by alcohol consumption, Croatia - № 11, Serbia - № 32, Italy - № 37, USA - № 56. Per capita alcohol consumption in modern Russia is an average 15.76 litres of pure alcohol. To compare with the year 1912 per capita alcohol consumption in Russia was 3.14 litres of pure alcohol. In WHO opinion per capita alcohol consumption over 8.0 litres of pure alcohol is a national danger.

Aid programs for alcohol addicted people exist in the USA for over 100 years. In connection with obsolescence of the most popular and wide-spread Alcoholics Anonymous approach founded in 1930-1940 - other programs are actively developing now.

Correnspodence to: Ekaterina Sobornikova Medical Academy of Continous Professional Education Moscow

e-mail: 4izm@mail.ru
In Russia social sobriety movement has a history of more than 130 years' experience. From the middle of the 19th century there was an active social sobriety movement connected with such names as a great Russian teacher and public figure Rachinsky S.A., the archpriest Alexander Rozhdestvensky, St. Righteous John of Kronstadt. However scientifically based aid programs for alcohol addicted people have spread in the USSR only in the eighties of the XX Century.

In Croatia the development of scientific aid program for alcohol addicted has started in the sixties of the XX Century and is connected with the name of a world-famous psychiatrist Vladimir Hudolin (2.05.192226.12.1996). Vladimir Hudolin has graduated from the chair of nervous and mental diseases of medical faculty of the Zagreb university, the chair was based in 1921 by a distinguished psychoneurologist, professor, Russian nobleman Lapinskiy Michail Niki- 
tovich (1862, Russia - 1949, Argentina). Doing an internship in Great Britain and Scotland clinics in 1952-1953, Vladimir Hudolin has got acquainted with clinical psychiatrist and the pioneer of social psychiatry Joshua Birer who has created in 1938-1939 the first therapeutic social club for patients of lunatic asylum and also with Maxwell Jones and his therapeutic community in Belmont hospital (Henderson Hospital). On the base of psychoneurological office of university hospital named after "Doctor Mladen Stojanović" Vladimir Hudolin on his returning to Zagreb has organized "open doors" system suggested by Scottish psychiatrist John Batty Tyyuk. He has also begun to implement there a therapeutic communities methodology, strategy of work in small groups and family approach.

"Rising star of social psychiatry"- the president of World association of social psychiatry A. Guilherme Ferreira has said about 45-year-old Vladimir Hudolin. Hudolin on the base of experience, theory of systems of Bertalanfi and reflections of his own began to develop social-ecological theory of alcoholism. According to this approach - problems connected with consumption of alcohol and other psychoactive agents are to be considered in the context of deviant behavior and lifestyle of addicted person. In this regard it is necessary to take into consideration the influence of immediate environment and inhabitable environment in general on the individual i.e., to estimate the influence of both individually-psychological and sociocultural factors.

On April 1, 1964 Vladimir Hudolin being already a doctor of medical sciences opens at university hospital the Croatia's first The Club System for Treated Alcoholics. By 1979 there were already over 2000 such clubs on the Balkans, and currently the club aid pro- gram has spread not only in the countries of the former Yugoslavia but also in more than 30 countries worldwide. The results of the efficiency of this program were amazing as they have shown that among clubs members about 60\% had permanent long remission.

In Russia wide range of experts became familiar with Vladimir Hudolin's method after an article published by B. Gachich, T.P. Neborakova and E.A. Koshkina in "Journal of Addiction Problems". In 1994 an article by A.N. Baburin together with a group of authors was published, in the article Russian experts have shared their experience in Family Clubs of Sobriety (FCS) management in Moscow and Moscow area.

In Russia Clubs of Sobriety based on Vladimir Hudolin's methodology were developing at the temples of Russian Orthodox Church that has become possible due to cooperation of the chief narcologist of the Ministry of Health of the Russian Federation V. F. Egorov and the representative of the external church relations department of ROC abbot Irinarkh (Grezin) in 1990-1991. Italian priest Silvio Frank during his visit in Moscow in 1991 has suggested to use Vladimir Hudolin's approach as a rehabilitation program for alcohol addicted people. In August 1992 Don Silvio together with the director of Italian «Centro studi sui problemi alcolcorrelati in Trento» professor Renzo De Stephanie, have made arrangements for cooperation with the Chairman of Synodal Department for Church Charity and Social Ministry of ROC archbishop Sergy Solnechnogorsky (Fomin). The first specialists in Clubs work among them the priest Alexey Baburin have received training in Italy in 1992, after that on December 5, 1992 the first Family Club of Sobriety in Russia was opened at St. Nicholas Church in Romashkovo village. The Italian 
colleagues have taken part in the organization of the first club in Russia: Don Silvio Frank, Don Edzio "Nilo" Kadonna, professor Renzo de Stephanie, medical workers Carlo Tenni and Roberto Cuni

Russian specialists and Russian Orthodox Church representatives have considered extremely important that Family Clubs of Sobriety were the communities of families solving the problems of alcohol and other psychoactive agents` addiction by virtue of family approach and gaining skills of sober life on the base of spiritually-moral improvement. The Club represented the organization, open for cooperation. All family members participating in Club's work, gradually got rid of alcoholic behavioral stereotypes, became conscious abstainers and got involved into socially useful activity.

It has been noted that each of the Club members had its own role and an emphasis was put on a permanent continuous training of the Club's emcee. Development of Family Clubs of Sobriety at the parishes of Russian Orthodox Church has specified that not an educational background was most important for the Club's emcee but his or her willingness to help one's neighbor, aspiration to share love with people around. Constant improvement of knowledge and professional retraining could let an emcee being not a professional expert to be engaged in Club's work. In 1993 and 1994 the first training courses in Russia for the specialists of Family Clubs of Sobriety have been conducted. More than 150 people were trained (narcologists, psychologists, priests, volunteers), however only the insignificant number of clubs was opened. Hereafter the family approach of Family Clubs of Sobriety comparing favourably with the program of "Anonymous alcoholics" contributed to active involve- ment of priests and volunteers with orthodox world-view in rehabilitation activity. Traditional family values on which the work of Family Clubs of Sobriety was based turned out to be conformable to values of the orthodox believing person. Furthermore accumulated in a Christian way of life the spiritual ascetic experience of fight with passions has allowed to enrich Vladimir Hudolin's program in Russia having expanded its spiritual component.

It should be noted that the Russian name of the club's work program - "Parish Family Clubs of Sobriety" - reflects an essence of group family approach in sobriety finding. Primary target of the Club's members is not only the resignation of psychoactive agents' consumption but striving to change their behavior, aspiration for personal creative evolution, training in falling in love with life again. At the Club's meetings they do not discuss policy and questions of alcoholization; religious subject can be mentioned only in the presence of the catechist which has got vocational education, it is necessary for the correct understanding of theological questions. Development of the Clubs at the church parishes has added to their name the words "orthodox" and "parish".

Church sacraments, personal and public prayers, vicarial and iatrotechnics, psychagogycal and psychocorrectional work of social workers and psychologists, active life of parish - all of that has a beneficial influence on OPFCS members. The vicarial followup is based on experiment and theoretical knowledge of orthodox anthropology, an ascetics and also on centuries-old experience of Church in care of souls. OPFCS draw families to traditional Christian ethical standards and values, but do not substitute by themselves church communities. OPFCS mem- 
bers are warned against danger to fall into new types of pathological addictions including club guardianship, and also against an attempt to create an idol of supervaluable idea of sobriety.

Family Clubs of Sobriety experience at the parishes of Russian Orthodox Church from 1992 to 2008 was reported in published in the magazine "Narkologiya" the article of priest Alexey Baburin the head of the Russian program of Orthodox Parish Family Clubs of Sobriety (OPFCS). Further expansion of clubs has led in 2011 to creation of Interregional social movement for Family Clubs of Sobriety (ISM FCS) headed by the priest Alexey Baburin. It should be noted that in April 2016 there are in Russia 23 OPFCS at temples and 2 OPFCS at the public narcological institutions. Weekly according to the Club's program more than 250 afflicted and members of their families receive help in Moscow, Moscow area and other Russian regions, including rather remote region the Bashkiria republic. Russian Parish Family Clubs are rapidly growing by virtue of active involvement in their activity both specialists and volunteers.

Along with the development of organizational, scientific and methodical work, great attention was paid to educational activity within the Club's movement. So, in 2013 in Moscow two-month courses of employees of Family Clubs of Sobriety took place and were attended by about 80 people (priests, social workers, psychologists and volunteers). In the same year the year-round school for Club workers was organized and more than 20 people are annually trained in it. Since 2015 the basic school for addicted people and members of their families began to function, teaching the principal knowledge of narcology and family psychology. The school also teaches basic principles of solving substance abuse problems.

In accordance with Vladimir Hudolin's ideas Parish Family Clubs of Sobriety work closely with scientifically-educational and clinical centers of narcology and psychiatry in Russia. Since 2013 till 2015 through the collaboration with the associate professor of narcology chair of Russian Medical Academy of Postdegree Education (RMAPE), Candidate of Medical Sciences, E.A. Sobornikova, was worked out guidance manual "Family Clubs of Sobriety as a rehabilitation method in the system of the narcological help". The vast experience of instructorship in Family Clubs of Sobriety and in narcology in whole was generalized during interdisciplinary scientific and practical Conference "Therapy of the family relations as a way of addictions prevention", and also in organized by E.A. Sobornikova a refresher course "Multidisciplinary approach to rehabilitation of patients with narcological profile" which took place on the basis of RMAPE in 2015.

In 2011 ISM FCS has started its program in the cooperation with the Department of endogenous psychological disorders and affective state research of Mental Health Research Center (MHRC) (the head - the academician of the Russian Academy of Sciences Alexander Sergeevich Tiganov) incorporating specific forms of mental pathology studying group (the research supervisor - Candidate of Medical Sciences, G. I. Kopeyko). The group was created to study the features of clinical psychopathological signs of mental disorders of mental patients with religious outlook. On the base of MHRC was conducted a longitudinal research aimed at determination of duration and quality of remittence of the people who have received the help in Parish Family Clubs of Sobriety. 
53 individuals, among them 35 males (66\%), 18 females (34\%) with the duration of alcoholism from 2 to 12 years were inspected by clinical reteach methods and questionnaires "Short Form-36 Health Status" and "Simptom Check List-90-Revised" (SCL-90-R).

As a result of research it has been defined that remittence from a month to half a year was registered among 5 individuals (10\%), remittance from half a year to a year among 13 individuals $(24,5 \%)$, remittance more than a year among 35 individuals (65.5\%). Quality of life in remittence (by SF-36) increased from low measures (lower than 130 points) up to medium (from 130 to 210 points - 40 individuals) and high measures (over 210 points -8 individuals). The satisfaction from life and realistic attitude to itself were formed (SCL-90-R). 40 individuals $(76 \%)$ have increased their level of socialization, 26 individuals $(50 \%)$ have normalized their family relations, 10 individuals $(19 \%)$ have got married, some of them even have had children. 24 individuals $(45 \%)$ have restored their professional skills, 12 individuals $(23 \%)$ have mastered new kinds of activity.

The researches have assumed that Parish Family Clubs of Sobriety approach is highly effective due to multidisciplinary approach, continuous rehabilitation, simultaneous participation in the program both addicted patients and their relatives, deep axiological reorientation of an individual in consequence of spiritual element actualization. Remittance became the result of a patient's responsible choice after rehabilitation of interpersonal relations in family in the process of group family work, and patient's personality was harmonized due to spiritual-oriented communication in specially organized psychotherapeutic environment. It was noted that changes of a patient's behavior were accom- panied with the changes of the whole lifestyle.

Results of the research conducted on the base of MHRC were reported on the Third Croatian-Russian international Congress of spiritual psychiatry which took place in Opatija city in March, 2015. During the Congress the head of ISM FCS, Senior Research Scientist of specific forms of mental pathology studying group of the Department of endogenous psychological disorders and affective state research of MHRC, archpriest Alexey Baburin and junior researcher of specific forms of mental pathology studying group of the Department of endogenous psychological disorders and affective state research of MHRC Andrey Magay could visit a grave of a distinguished Croatian psychiatrist, founder of the family clubs of sobriety program Vladimir Hudolin where the archpriest Alexy Baburin has chanted a requiem. That was also when they have had meeting with the head of the Croatian union of The Club System for Treated Alcoholics professor Zoran Zoričić In the course of the meeting it was agreed on professor's visit to Moscow and on the participation of representatives of the Russian and Croatian Family Clubs of Sobriety programs in the international Conference in Moscow in 2016.

A scientific conference with international participation "Problems of psychosocial rehabilitation of mental patients with religious outlook" took place on the base of MHRC on March 29 during the visit in Moscow of Zagreb University professor Zoran Zoričić and Belgrad University professor Peter Nastasić. At the conference there were represented reports on different aspects of modern psychosocial rehabilitation of mental patients with religious outlook including approaches of help to people with mental 
disease and addiction problems. In welcome speech to conference members the head of MHRC, academician of the Russian Academy of Sciences A.S. has said "Rehabilitation of mental patients and alcohol and narcological addicted patients continues to be one of the central problems not only medicine, but society. At this conference it will be a question of an original approach in which spiritual and religious aspects of help are not in the last place but are of great importance along with special medical ways of impact on patients".

During the working visit to Moscow, prof. Zoričić and prof. Nastasić were invited to Medical Academy that provides postgraduate studies, where further cooperation was arranged. The importance of the rehabilitation of the addicts was accentuated, and prof. Zoričić and prof. Nastasić also did the short education and supservision of the work in the Clubs. As well, the agreement about the following family treatment training was established.

In the conclusion it would hopefully that further development of the international cooperation of the Russian and European experts in sobriety club movement area will contribute to the enrichment of sharing experience in solving problems of alcohol and other psychoactive agents consumption, as well as will bear lots of other fruits of creative communication and friendship between historically close nations. 